\title{
THE POTENTIALS OF CAPTURE FISHERIES COMMODITIES FOR MEETING THE NEEDS OF TOURISM SECTOR IN CENTRAL BANGKA REGENCY OF INDONESIA
}

\author{
Valeriani Devi, Wibawa Dian Prihardini, Lecturers \\ Faculty of Economics, Bangka Belitung University, Indonesia \\ Saputra Herry Marta, Lecturer \\ Faculty of Agriculture, Fisheries, and Biology, Bangka Belitung University, Indonesia \\ *E-mail: deviyono92@gmail.com
}

\begin{abstract}
In 2010, Central Bangka Regency was one of 197 regencies in Indonesia designated by The Ministry of Maritime Affairs and Fisheries as a minapolitan area in the Bangka Belitung Island Province. The potential of agriculture,marine and fisheries in Central Bangka Regency is very large, so it needs to be supported by a variety of policies, programs and development activities in the marine and fisheries sector in order to suport the tourism sector in order to support the tourism sector as to realize community independence. The support of the capture fisheries sector in meeting the needs of tourist, hotels, restaurants, culinary and souvenirs of processed fish is very much needed. This study uses the Location Question (LQ) approach with secondary data to determine the minapolitan potential of capture fisheries as ab effort to meet the needs of the tourism sector. The result in this study states that $50 \%$ of the small pelagic fish catagories have an LQ Value $>1,42,85 \%$ of the large pelagic fish catagory have LQ Value> 1, $57.69 \%$ the demersal fish catagory has an LQ Value $>1.71,52 \%$ of the reef fish catagory had an LQ Value $>1,60 \%$ of the hard-skinned fish catagory had an LQ Value> 1 , and $50 \%$ for the soft-bodied fish catagory had anLQValue $>1$. These results indicate that $55,35 \%$ of capture fisheries commodities in Central Bangka Regency have been able to meet the needs of the tourism sector area.
\end{abstract}

\section{KEY WORDS}

Capture fisheries, main commodities, tourism sector, public service.

The fisheries sector has the potential to become a prime mover and plays an important role for the economy, especially the national economy, but has not been managed optimally. The management is still based on the principles of integration, efficiency, quality and acceleration(Aswanah et al., 2013). Planning for optimal utilization of fisheries and marine resources must be based on the potential of existing resources (Arifin \& Suryawati, 2013; Kumaat et al., 2013). One of the fisheries sectors which is expected to be a leading sector is the capture fisheries sector. Sustainability of capture fisheries on an ecological basis is an important part of capture fisheries development (Abdullah et al., 2011; Tibrani, 2018). Fisheries production in the capture fisheries sector in Indonesia is mostly derived from smallscale or traditional fishing businesses using small boats so that the reach is limited and relatively small (Antika et al., 2014; Nurkholis et al., 2016; Cikitha et al., 2018). The development of fisheries must be designed and formulated as fully as possible to be able to face various kinds of challenges (Wahyuningrum et al., 2012).

The results of studies of various researchers stated that the main problem of small scale capture fisheries business actors is the limited assets and capital, seasonality and the risk of uncertainty due to limited information and data (Koeshendrajana et al., 2012). Hastuti et al. (2013) concluded, distant fishing ground can have an impact on increasing time to sea, the situation has a negative impact on the level of income of fishermen. Revenue aspect as a strategic key to the success of fishing business through marketing outputs, with the hope of being able to obtain an indication of fishing business activities can be done with efficient, 
effective and rational (Mulyanto \& Subekti, 2010; Nazira et al., 2015). In addition, problems faced by fishermen in general are limited capital for fishermen to improve their businesses, low quality of human resources where the level of education / skills possessed by fishermen is low, and weak supervision (Aswanah et al., 2013). In an effort to create sustainable management, identification of various factors that influence must also be known so that improvements can be made towards a better direction (Radarwati et al., 2010; Nurkholis et al., 2016).

Indonesia has a vast and strategically significant sea area as a pillar of national economic development. Besides having economic value, marine resources also have ecological benefits. The geo-economic and geo-political conditions make the marine sector an important sector in national development. For this reason, this potential must be optimally and sustainably utilized (Panhwar et al., 2012; Maradong, 2016). In addition to being a source of community income, the capture fisheries sector is a mainstay for coastal communities as a source of livelihood (Asiati \& Nawawi, 2016). In 2011, the number of capture fisheries households increased 0.86 percent or reached 920,129 households (KKP, 2012). The fishing community itself is a coastal community group whose main livelihood is fishing in the sea (Ma'arif et al., 2016; Tibrani, 2018).

Central Bangka Regency is one of the newly established districts in the Bangka Belitung Province, which has the aim of developing the region by promoting the tourism sector as one of the potential sectors. The development of the tourism sector in Central Bangka Regency is seen from the increasing number of tourists visiting in 2017 as many as 85,778 people and in 2018 it increased to 96,457 people. The support of the capture fisheries sector in meeting the needs of tourists, hotels, restaurants, culinary and souvenirs of processed fish is very much needed. This indicates the need to strengthen the capture fisheries sector in sustainable tourism development is defined as a tourism development process oriented to the resources needed for future development.

In 2010, Central Bangka Regency was one of 197 districts in Indonesia and one of four districts in the Bangka Belitung Islands Province which was determined by the Ministry of Maritime Affairs and Fisheries as a Minopolitan Area. The potential of marine and fisheries in Central Bangka Regency is very large, so that the potential needs to be supported by various policies, programs and development activities in the marine and fisheries sector in order to support the tourism sector so that community independence can be realized. The high potential of fisheries is seen from the results of the 2016 period of $23,606.50$ tons, and increased in 2017 to $23,969.66$ tons.

The availability of large minapolitan potential in the form of capture fisheries sector is a form of business to meet the needs of the tourism sector in Central Bangka Regency. However, the magnitude of this potential can lead to over exploitation that occurs when utilization is greater than the optimum catch (Setyaningrum, 2013; Daudpota et al., 2014). Purnomo (2012), Tamarol et al. (2012) said that overfishing and environmental degradation from fishery activities results in changes in aquatic ecosystems.Correct fisheries management is expected to be able to provide support for national development with positive contributions in relation to pro-growth, namely the contribution of the capture fisheries subsector to national economic development, pro-poor, namely foreign exchange earnings through exports, non-tax state revenue and to reduce poverty, pro- job that is helping to overcome multidimensional crises both in the form of providing employment, and proenvironment (Triarso, 2013; Purwanto \& Wudianto, 2017).

Potential Capture Fisheries Commodity Research to Meet the Needs of the Tourism Sector in Central Bangka Regency is an effort to find out how much the potential of minapolitank resources specifically capture fisheries commodities are able to meet the needs of the tourism sector.

\section{THEORETICAL REVIEW}

The definition of fisheries according to the law refers to the statute number 45 of 2009 , which is all activities related to the management and utilization of fish resources and the 
environment, from pre-production, production, processing to marketing, which are carried out in a fisheries business system. Other definitions mention capture fisheries are activities of capturing / collecting animals and aquatic plants, both at sea and in public waters freely.

Capture fisheries production in Central Bangka Regency, Bangka Belitung Islands Province, in 2016 reached 23,606.50 tons. The role of capture fisheries in Central Bangka Regency in supporting the tourism sector is various foods that are processed from the processed fishery industry. Fish as raw material for making snacks for souvenirs, shredded fish, and other food products made from fish. In addition to processed fisheries, capture fisheries productions are usually carried out by housewives. The local government continues to encourage the business to become a major supporter of the tourism sector and ultimately can support the family economy.

Leading commodity is a mainstay commodity which has a strategic position to be developed in an area whose determination is based on various considerations both technically (land and climate conditions) and socio-economic and institutional (technology mastery, resource capability, human, infrastructure, and social conditions Local culture Determination of superior commodities in an area is a necessity with consideration of the ability of an area to produce and market commodities that are in accordance with the land and climate conditions in a particular region is also very limited. another, because besides having comparative advantage it also has high business efficiency.

The role of the tourism sector is increasingly important in line with the development and contribution of the tourism sector through foreign exchange earnings, regional income, regional development, as well as in the absorption of investment and labor and business development that is spread in various parts of Indonesia. According to the Ministry of Tourism Pocket Book (2016), the contribution of the tourism sector to the national Gross Domestic Product (GDP) in 2014 has reached $9 \%$ or as much as Rp 946.09 trillion. While foreign exchange from the tourism sector in 2014 reached Rp 120 trillion and contributed to employment opportunities of 11 million people. Theoretically, tourism is everything related to tourism, including tourism object entrepreneurs, tourist attractions and businesses related to tourism. Tourism must meet the following four criteria, namely: 1) travel is carried out from one place to another, travel is done outside the residence where the person usually lives; 2) the purpose of the trip is done solely for fun, without making a living in the country, city or DTW visited. 3) the money spent by the tourist is brought from his home country, where he can live or live, and is not obtained because of the results of his business while on the tour; and 4) the trip must be made at least 24 hours or more.

\section{METHODS OF RESEARCH}

The variables observed or measured in this study were capture fish production to measure their potential in meeting the needs of the tourism sector. The fisheries sector itself is divided into the capture fisheries sub-sector and the aquaculture sub-sector, and what is used in this study is the capture fisheries sub-sector.

Location Quotient is an analysis technique used to determine the basis and non-base sectors, with the aim of seeing the comparative advantage of an area in determining its superior sector. The economic activities of an area can be divided into two groups, namely:

- The base sector is an economic sector that is able to meet the needs of both the domestic market and markets outside the region itself. This means that this sector in its activities is able to meet the needs of the region itself and other regions and can be used as a superior sector;

- Non-base sector is an economic sector that is only able to meet the needs of the region itself, a sector such as this is known as the non-leading sector.

The Location Quotient (LQ) formula according to Bendavid Val which is then used in determining the basis and non-base sectors in this study, is stated in the following equation:

$$
\mathrm{LQ}=\frac{\mathrm{Si} / \mathrm{Ni}}{\mathrm{S} / \mathrm{N}}
$$


Where: $\mathrm{Si}=$ income (production) sub sector $\mathrm{i}$ at the district level; $\mathrm{Ni}=$ Revenue (production) totals of the district; $S=$ Income (production) sub sector $i$ at the provincial level; $N=$ Revenue (production) of the total provincial sub-sector.

Calculation model that is made to get the results of Location Quotient (LQ) of Central Bangka Regency can be expressed through equations. If $L Q>1$, then the sector is the base sector and if $L Q<1$, then the sector is a non-base sector. The $L Q$ formulation structure gives the following values:

(1) $L Q>1=$ means that the growth rate of sub sector $i$ in the study area $k$ is greater than the growth rate of the same sub sector in the economy of the reference area p. Thus, the $\mathrm{p}$ sub-sector is the basic sub-sector to be further developed by the area under study $\mathrm{k}$.

(2) $L Q<1$ : it means that the growth rate of sub sector $\mathrm{i}$ in the study area $\mathrm{k}$ is smaller than the growth rating of the same sub sector in the economy of the reference area $\mathrm{i}$. Thus, sub sector $i$ is not a base sector.

(3) $L Q=1$ : means the growth rate of sub sector $i$ in the area studied $k$ is the same as the growth rate of the same sub sector in the economy of the reference area $p$.

\section{RESULTS AND DISCUSSION}

The Potential capture fisheries commodities are measured from the Location Question (LQ) of capture fisheries. The results of the Location Question (LQ) calculations from 2011 to 2016 are shown in Table 1. Based on results of the analysis of the potential of Tangkappa fisheries in small pelagic fish commodities, it was found that mullet fish, japuh, bollocks, bloating, komo, selar, selet, selet, terubuk, and tetengkek are small pelagic fish commodities that can meet the needs of the area including the needs of the tourism sector and it can even export to other regions because it has a $L Q$ value above 1 . While other fish such as anchovies, bentong, bamboo leaves / chamfer, banyar, lemuru, siro, green string, yellow string, and song have not been able to meet the needs of the regions themselves are only able to meet their own needs and the shortcomings must be brought from outside Central Bangka Regency. This is because the LQ value of the two commodities does not reach 1.

Based on the results of the analysis of the potential of Tangkappa fisheries in small pelagic fish commodities, it was found that mullet fish, japuh, bollocks, bloating, komo, selar, selet, selet, terubuk, and tetengkek are small pelagic fish commodities that can meet the needs of the area including the needs of the tourism sector and it can even export to other regions because it has a $L Q$ value above 1 . While other fish such as anchovies, bentong, bamboo leaves / chamfer, banyar, lemuru, siro, green string, yellow string, and song have not been able to meet the needs of the regions themselves are only able to meet their own needs and the shortcomings must be brought from outside Central Bangka Regency. This is because the $L Q$ value of the two commodities does not reach 1.

In addition to small pelagic fish commodities, large pelagic fish commodities also become a staple for the tourism sector. The results of the calculation of LQ value on large pelagic fish commodities are found that, types of fish that can meet the needs of the area include the needs of the tourism sector and can even export to other regions are krai cobs $(L Q=3.23)$; mackerel $(L Q=1.34)$, stripped $(L Q=2.58)$. Whereas the types of gray tuna, komo tuna, mackerel boards, and bottle cones have not been able to meet the needs of the region itself. This is because the LQ value of the four commodities does not reach 1 , which is caused by, among others, weather factors. These factors determine the level of production of these fish species. Because fishermen still have difficulty changing the work strategies that have been implemented for years and when the weather is not favorable they prefer to vacuum to do fishing (Nugrayasa, 2012). In order to meet the needs of the four types of fish for economic activities in the tourism sector such as the needs of the hotel, restaurant, and culinary industry, the shortage of supplies is imported from outside Central Bangka Regency.

Demersal fish commodity consisting of 26 types of fish (can be seen in Table 4.1) is a commodity in Central Bangka Regency, only from 26 species of fish there are 11 types of fish that are not included as potential commodities because the LQ value is less than 1 and only sufficient for one's own needs have not been able to meet the needs of other regions. 
Table 1 - Potential of Capture Fisheries Commodities in Central Bangka Regency in 2011-2016

\begin{tabular}{|c|c|c|c|}
\hline No & Small Pelagic Fish Commodities & LQ Value(Average 6 Years) & Note \\
\hline 1 & Teri & 0,91 & Non Basis \\
\hline 2 & Belanak & 1,37 & Basis \\
\hline 3 & Bentong & 0,03 & Non Basis \\
\hline 4 & Daun Bambu/Talang-talang & 0,59 & Non Basis \\
\hline 5 & Japuh & 1,14 & Basis \\
\hline 6 & Julung-julung & 3,96 & Basis \\
\hline 7 & Banyar & 0,16 & Non Basis \\
\hline 8 & Kembung & 2,67 & Basis \\
\hline 9 & Lemuru & 0,17 & Non Basis \\
\hline 10 & Siro & 0,84 & Non Basis \\
\hline 11 & Selar Komo & 1,68 & Basis \\
\hline 12 & Selar Hijau & 0,54 & Non Basis \\
\hline 13 & Selar Kuning & 0,48 & Non Basis \\
\hline 14 & Selar & 2,54 & Basis \\
\hline 15 & Tembang & 0,75 & Non Basis \\
\hline 16 & Selanget & 1,35 & Basis \\
\hline 17 & Terubuk & 4,09 & Basis \\
\hline 18 & Tetengkek & 1,69 & Basis \\
\hline No & Large Pelagic Fish Commodities & LQ Value(Average 6 Years) & Note \\
\hline 1 & Tongkol Abu-abu & 0,05 & Non Basis \\
\hline 2 & Tongkol Komo & 0,10 & Non Basis \\
\hline 3 & Tongkol Krai & 3,23 & Basis \\
\hline 4 & Tenggiri & 1,34 & Basis \\
\hline 5 & Tenggiri Papan & 0,11 & Non Basis \\
\hline 6 & Cucut Botol & 1,81 & Non Basis \\
\hline 7 & Cucut Lanyam & 2,58 & Basis \\
\hline No & Demersal Fish Commodities & LQ Value(Average 6 Years) & Note \\
\hline 1 & Manyung & 0,99 & Basis \\
\hline 2 & Ikan Sebelah & 1,68 & Basis \\
\hline 3 & Kuwe & 0,37 & Non Basis \\
\hline 4 & Bawal Hitam & 0,74 & Non Basis \\
\hline 5 & Bawal Putih & 1,13 & Basis \\
\hline 6 & Golok-golok & 4,09 & Basis \\
\hline 7 & Beloso/Buntut Kerbo & 1,26 & Basis \\
\hline 8 & Ikan Lidah & 2,35 & Basis \\
\hline 9 & Ikan Gaji & 1,35 & Basis \\
\hline 10 & Ikan Nomei/Lomei & 0,98 & Non Basis \\
\hline 11 & Peperek & 1,68 & Basis \\
\hline 12 & Lencam & 0,31 & Non Basis \\
\hline 13 & Kakap Putih & 1,75 & Basis \\
\hline 14 & Kakap Batu & 0,03 & Non Basis \\
\hline 15 & Kakap Merah/Bambangan & 0,34 & Non Basis \\
\hline 16 & Kurisi & 1,68 & Basis \\
\hline 17 & Biji Nangka & 0,73 & Non Basis \\
\hline 18 & Kuro/Senangin & 0,91 & Non Basis \\
\hline 19 & Gulamah/Tigawaja & 1,13 & Basis \\
\hline 20 & Rejung & 0,48 & Non Basis \\
\hline 21 & Alu-alu/Manggilala/Pucul & 2,89 & Basis \\
\hline 22 & Pari Kembang/Pari Macan & 0,56 & Non Basis \\
\hline 23 & Pari Burung & 2,36 & Basis \\
\hline 24 & Pari Kekeh & 6,58 & Basis \\
\hline 25 & Kambing-kambing/Ayam-ayam & 1,59 & Basis \\
\hline 26 & Sembilang & 1,89 & Basis \\
\hline No & Coral Fish Commodities & LQ Value(Average 6 Years) & Note \\
\hline 1 & Ekor Kuning/Pisang-pisang & 1,00 & Basis \\
\hline 2 & Kerapu Karang & 1,21 & Basis \\
\hline 3 & Kerapu Balong & 0,88 & Non Basis \\
\hline 4 & Kerapu Lumpur & 1,52 & Basis \\
\hline 5 & Kerapu Sunu & 0,56 & Non Basis \\
\hline 6 & Beronang Lingkis & 1,94 & Basis \\
\hline 7 & Beronang Kuning & 2,09 & Basis \\
\hline No & Hard-skinned Commodities & LQ Value(Average 6 Years) & Note \\
\hline 1 & Udang Dogol & 2,03 & Basis \\
\hline 2 & Udang Putih/Jerbung & 0,20 & Non Basis \\
\hline 3 & Udang Krosok & 0,50 & Non Basis \\
\hline 4 & Kepiting & 2,21 & Basis \\
\hline 5 & Rajungan & 1,20 & Basis \\
\hline No & Soft-bodied Commodities & LQ Value(Average 6 Years) & Note \\
\hline 1 & Kerang Darah & 2,22 & Basis \\
\hline 2 & Cumi-cumi & 0,68 & Non Basis \\
\hline 3 & Sotong & 2,12 & Basis \\
\hline 4 & Gurita & 0,00 & Non Basis \\
\hline
\end{tabular}

Source: processed by researchers, 2019. 
While the rest are fish next door, white pomfret, machete-machete, beloso / oxtail, tongue fish, salted fish, pepperek, white snapper, curry, sugarcane / tigawaja, pestle / mallala / pucul, bird ray, kekeh ray, goats / chickens and cross breeds are potential commodities because of the availability of adequate resources, such as local raw materials, local resource skills, local production technology and other local infrastructure. Meeting the needs of the tourism sector from demersal fish commodities can be fulfilled by the region, because half of the types of fish in addition to meeting the needs of the region itself can be exported by these regions to other regions.

Commodities of reef fish as the needs of the tourism sector, which can be met by the production of the Central Bangka Regency are yellow tailed fish / bananas, coral grouper, mud grouper, circular beron, and yellow beron. These five types of fish have LQ values of more than one, so they are able to meet regional needs including the needs of the tourism sector and even able to export to other regions. Balong grouper and grouper fish are able to meet the needs of the area itself, because the $L Q$ value is less than 1, meaning that these types of fish can not be sent / exported outside the Central Bangka Regency.

In addition to several commodities that have been described, hard-skinned commodities also become a basic need for the tourism sector. The results of the calculation of LQ value on hard-skinned fish commodities are found that, the type of white shrimp and crustacean shrimp have not been able to meet the needs of the region itself. That is because the LQ value of the two types of warehouses does not reach 1, which is caused by, among others, hard-to-predict seasonal factors (Nurhayati, 2013). In order to meet the needs of the two types of shrimp for economic activities in the tourism sector such as the needs of the hotel, restaurant, and culinary industry, the supply of the shortage needs is brought in from outside Central Bangka Regency. While the types of fish that can meet the needs of the area including the needs of the tourism sector and can even export to other regions are dogol shrimp $(\mathrm{LQ}=2.03)$; crab (LQ = 2.21), crab $(\mathrm{LQ}=1.20)$.

Soft-bodied commodities consisting of blood shells, squid, cuttlefish and octopus are commodities found in Central Bangka Regency, it's just that pure octopus needs to be fully imported from outside Central Bangka Regency, because the LQ value is 0, meaning that the commodity is indeed not produced in this area. For this type of squid there is production but sufficient for the needs of the area including the tourism sector and other sectors, even if the needs of the region are not met then it will be met from outside the region. While blood clams and cuttlefish are soft-bodied commodities that are included as potential commodities due to adequate availability of resources and able to be exported by these regions to other regions. Meeting the needs of the tourism sector from soft-bodied commodities can be met by the area, but for squid only enough for their own needs have not been able to meet the needs of other regions.

The analyzed capture fisheries commodities besides having the potential of each commodity, must be supported by economic activities by encouraging regional market expansion (even with import substitution), encouraging capital circulation (recirculation) in the community, and encouraging learning processes. Other things that need to be strengthened are service facilities including production facilities (fishing gear, places and catch processing processing equipment), production support facilities (banking institutions, cooperatives, electricity), as well as marketing facilities (markets, transportation terminals, transportation facilities). The development of potential commodities must be focused so that they are right on the commodity that has the potential to be developed (Oksatriandhi \& Santoso, 2014) and in order to meet the needs of the tourism sector.

Capture fisheries commodities must be able to increase the economic strength of the community at the micro and small scale, increase the number and quality of processed business products, so that they can compete by paying attention to the principles of integration, efficiency, quality and acceleration. Nugraha (2014), Indonesia's enormous potential for the fisheries and marine sector has not been able to provide benefits for improving the welfare of the community due to the low productivity of the community in the fisheries sector. 


\section{CONCLUSION}

Some $50 \%$ of small pelagic fish categories have LQ value> 1 with the highest $L Q$ value is Terubuk fish. A total of $42.85 \%$ of the large pelagic fish categories have an LQ value> 1 with the highest $L Q$ value is tuna. A number of $57.69 \%$ categorized as demersalm have LQ value> 1 with the highest $L Q$ value of machete-machete fish. A total of $71.52 \%$ of the reef fish category has a LQ value> 1 with the highest value of yellow baronang fish. Some $60 \%$ of hard-skinned categories have a LQ value> 1 with the highest LQ value of crabs. Some $50 \%$ of soft-bodied fish categories have an LQ value> 1 with the highest $L Q$ value in blood shells.

LQ assessment results for all categories of capture fisheries indicate that capture fisheries commodities in Central Bangka Regency with an average value of $55.35 \%$ have been able to meet the needs of the tourism sector.

\section{ACKNOWLEDGEMENTS}

This research was funded by a grant from the University of Bangka Belitung and University Lecturer Research (PDTU) TA 2019 scheme. Thanks to BPS Kep Province. Bangka Belitung, the Office of Maritime Affairs and Fisheries of the Province of Babel, and the Office of Tourism of the Province of Babel and the Office of Tourism of Central Bangka Regency for the support of research data.

\section{REFERENCES}

1. Abdullah, R.M., Wisudo, S.H., Monintja, D.R. \& Sondita, M.F.A. (2011). Keberlanjutan perikanan tangkap di Kota Ternate pada dimensi ekologi. Buletin PSP, 19(1), 113-126.

2. Antika, M., Mudzakir, A.K. \& Boesono, H. (2014). Finansial feasibility study of Danish seine fishing in Fish Landing Center Ujung Batu. Journal of Fisheries Resources Utilization Management Technology, 3(3), 200-207.

3. Arifin, T. \& Suryawati, S.H. (2013). Analisis peranan sektor perikanan dalam mendukung program minapolitan di Provinsi Gorontalo: model input-output. Jurnal Sosial Ekonomi Kelautan and Perikanan, 8(2), 129-143.

4. Asiati, D. \& Nawawi, N. (2016). Kemitraan di sektor perikanan tangkap: strategi untuk kelangsungan usaha and pekerjaan. Jurnal Kependudukan Indonesia, 11(2), 103-118.

5. Aswanah, Y.K., Efani, A. \& Tjahjono, A. (2013). Evaluasi terhadap implementasi program pengembangan kawasan minapolitan perikanan tangkap di Pelabuhan Perikanan Nusantara (PPN) Brondong Kabupaten Lamongan Jawa Timur. Jurnal ECSOFiM, 1(1), 97-107.

6. Cikitha, P., Suryana, A.A.H., Anna, Z. \& Nurhayati, A. (2018). Analisis peran sektor perikanan terhadap pembangunan wilayah Kabupaten Kuningan Jawa Barat. Jurnal Perikanan Kelautan, 9(1), 1-8.

7. Daudpota, A.M., Kalhoro, I.B., Shah, S.A., Kalhoro, H. \& Abbas, G. (2014). Effect of stocking densities on growth, production and survival rate of red tilapia in hapa at fish hatchery Chilya Thatta, Sindh, Pakistan. Journal of Fisheries, 2(3), 180-186.

8. Hastuti, I., Bambang, A. \& Rosyid, A. (2013). Analysis of technical and economical aspect of drift gill net operation at Cilacap Fishing Port. Journal of Fisheries Resources Utilization Management and Technology, 2(2), 102-112.

9. KKP. (2012). Statistik Kelautan and Perikanan Indonesia Tahun 2012. Jakarta: Kementerian Kelautan and Perikanan Indonesia.

10. Koeshendrajana, S., Apriliani, T. \& Firdaus, M. (2012). Peningkatan Efektivitas and Efisiensi Usaha Perikanan Tangkap Laut Skala Kecil Melalui Fasilitasi Peta perkiraan fishing ground. Jurnal Kebijakan Sosial Ekonomi Kelautan and Perikanan, 2(1), 77-88.

11. Kumaat, J., Haluan, J., Wisudo, S.H. \& Monintja, D.R. (2013). Sustainable Potential of Fisheries Capture in Sitaro Island Regency. Marine Fisheries, 4(1), 41-50. 
12. Ma'arif, R., Zulkarnain, Nugroho, T. \& Sulistiono. (2016). Empowering of fisherman community through capture fisheries in Majakerta Village, Indramayu, West Java. Agrokreatif, 2(1), 17-24.

13. Maradong, D.S. (2016). Potensi Besar Perikanan Tangkap Indonesia.

14. Mulyanto, R. \& Subekti, T.S. (2010). Rancang Bangun Jaring Insang Dasar untuk Penangkapan Ikan Kakap Putih di Perairan Kabupaten Ketapang Kalimantan Barat. ARIOMMA, 27(2), 10-17.

15. Nazira, K., Yongtong, M., Kalhoro, M.A., Memon, K.H., Mohsin, M. \& Kartika, S. (2015). A preliminary study on fisheries economy of Pakistan: plan of actions for fisheries management in Pakistan. Canadian Journal of Basic Applied Sciences, 3(1), 7-17.

16. Nugraha, H. (2014). Model Produktivitas and Penyerapan Tenaga Kerja Perikanan Tangkap di Pantai Untara Jawa Barat (Aplikasi Persamaan Simultan Harga and Upah). Jurnal SMART, 11(1), 67-76.

17. Nurkholis, N., Nuryadin, D., Syaifudin, N., Handika, R., Setyobudi, R.H. \& Udjianto, D.W. (2016). The economic of marine sector in Indonesia. Aquatic Procedia, 181-186. doi:10.1016/j.aqpro.2016.07.025

18. Oksatriandhi, B.B. \& Santoso, E.B. (2014). Identifikasi Komoditas Unggulan di Kawasan Agropolitan Kabupaten Pasaman. Jurnal Teknik Pomits, 3(1), 8-11.

19. Panhwar, S.K., Liu, Q., Khan, F. \& Siddiqui, P.J.A. (2012). Maximum sustainable yield estimates of Ladypees, Sillago sihama (Forsskål), fishery in Pakistan using the ASPIC and CEDA packages. Journal of Ocean University of China, 11(1), 93-98. doi:10.1007/s11802-012-1880-3.

20. Purnomo, B.H. (2012). Peranan perikanan tangkap berkelanjutan untuk menunjang ketahanan pangan di Indonesia. Paper presented at the Seminar Nasional Kedaulatan Pangan and energi 2012, Fakultas Pertanian, Universitas Trunojoyo Madura, Juni 2012.

21. Purwanto, P. \& Wudianto, W. (2017). Perkembangan and optimisasi produksi perikanan laut di Indonesia. Jurnal Kebijakan Perikanan Indonesia, 3(2), 81-99.

22. Radarwati, S., Baskoro, M.S., Monintja, D.R. \& Purbayanto, A. (2010). Analisis faktor internal - eksternal and status keberlanjutan pengelolaan perikanan tangkap di Teluk Jakarta. Jurnal Teknologi Perikanan and Kelautan, 1(1), 1-13.

23. Setyaningrum, E.W.J.I.J.o.E. (2013). Penentuan Jenis Alat Tangkap Ikan Pelagis yang Tepat and Berkelanjutan dalam Mendukung Peningkatan Perikanan Tangkap di Muncar Kabupaten Banyuwangi Indonesia. Jurnal Pembagunan and Alam Lestari, 4(2), 45-50.

24. Tamarol, J., Luasunaung, A. \& Budiman, J. (2012). The impact of fishing fisheries on the fish resources and their habitats in Tabukan Tengah Waters, Kepulauan Sangihe. Jurnal Perikanan and Kelautan Tropis, 8(1), 12-16.

25. Tibrani, T. (2018). Peranan subsektor perikanan dalam menunjang perekonomian Kabupaten Kampar Provinsi Riau. Jurnal Agribisnis, 20(2), 206-216.

26. Triarso, I. (2013). Potency and development opportunity of bussines capture fisheries in North Coastal of Central Java. Jurnal Saintek Perikanan, 8(2), 6-17.

27. Wahyuningrum, P.I., Nurani, T.W. \& Rahmi, T.A. (2012). Usaha perikanan tangkap multi purpose di Sadeng, Kabupaten Gunungkidul, Daerah Istimewa Yogyakarta. Maspari Journal, 4(1), 10-22. 